\title{
Rapid transfer of photosynthetic carbon through the plant-soil system in differently managed species-rich grasslands
}

\author{
G. B. De Deyn ${ }^{1,2}$, H. Quirk ${ }^{1}$, S. Oakley ${ }^{3}$, N. Ostle ${ }^{3}$, and R. D. Bardgett ${ }^{1}$ \\ ${ }^{1}$ Soil and Ecosystem Ecology Laboratory, Lancaster Environment Centre, Lancaster University, Lancaster LA1 4YQ, UK \\ ${ }^{2}$ Department of Terrestrial Ecology, Netherlands Institute of Ecology, P.O. Box 50, 6700 AB Wageningen, The Netherlands \\ ${ }^{3}$ Centre for Ecology and Hydrology, Lancaster Environment Centre, Lancaster LA1 4AP, UK
}

Received: 22 January 2011 - Published in Biogeosciences Discuss.: 2 February 2011

Revised: 10 May 2011 - Accepted: 11 May 2011 - Published: 13 May 2011

\begin{abstract}
Plant-soil interactions are central to short-term carbon (C) cycling through the rapid transfer of recently assimilated $\mathrm{C}$ from plant roots to soil biota. In grassland ecosystems, changes in $\mathrm{C}$ cycling are likely to be influenced by land use and management that changes vegetation and the associated soil microbial communities. Here we tested whether changes in grassland vegetation composition resulting from management for plant diversity influences shortterm rates of $\mathrm{C}$ assimilation and transfer from plants to soil microbes. To do this, we used an in situ ${ }^{13} \mathrm{C}-\mathrm{CO}_{2}$ pulselabelling approach to measure differential $\mathrm{C}$ uptake among different plant species and the transfer of the plant-derived ${ }^{13} \mathrm{C}$ to key groups of soil microbiota across selected treatments of a long-term plant diversity grassland restoration experiment. Results showed that plant taxa differed markedly in the rate of ${ }^{13} \mathrm{C}$ assimilation and concentration: uptake was greatest and ${ }^{13} \mathrm{C}$ concentration declined fastest in Ranunculus repens, and assimilation was least and ${ }^{13} \mathrm{C}$ signature remained longest in mosses. Incorporation of recent plantderived ${ }^{13} \mathrm{C}$ was maximal in all microbial phosopholipid fatty acid (PLFA) markers at $24 \mathrm{~h}$ after labelling. The greatest incorporation of ${ }^{13} \mathrm{C}$ was in the PLFA $16: 1 \omega 5$, a marker for arbuscular mycorrhizal fungi (AMF), while after 1 week most ${ }^{13} \mathrm{C}$ was retained in the PLFA 18:2 $\omega 6,9$ which is indicative of assimilation of plant-derived ${ }^{13} \mathrm{C}$ by saprophytic fungi. Our results of ${ }^{13} \mathrm{C}$ assimilation and transfer within plant species and soil microbes were consistent across management treatments. Overall, our findings suggest that plant diversity restoration management may not directly affect the $\mathrm{C}$ assimilation or retention of $\mathrm{C}$ by individual plant taxa or groups of soil microbes, it can impact on the fate of recent $\mathrm{C}$ by
\end{abstract}

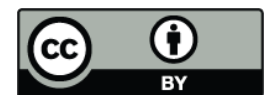

Correspondence to: G. B. De Deyn (gerlindede@gmail.com) changing their relative abundances in the plant-soil system. Moreover, across all treatments we found that plant-derived $\mathrm{C}$ is rapidly transferred specifically to AMF and decomposer fungi, indicating their consistent key role in the cycling of recent plant derived $\mathrm{C}$.

\section{Introduction}

Considerable quantities of carbon (C) are stored in terrestrial vegetation with even more in soils (Ostle et al., 2009a), but this $\mathrm{C}$ is vulnerable to losses due to respiration, leaching via soil water, and erosion (Lal, 2004; Smith et al., 2007; Quinton et al., 2010). The main factors that determine rates of C loss via soil respiration are thought to be soil temperature and moisture (Davidson and Janssens, 2006). However, the underlying process of $\mathrm{C}$ mineralization is primarily governed by the activity of soil biota which are very responsive to plant $\mathrm{C}$ inputs and the transfer of recent photosynthetic $\mathrm{C}$ to soil via roots and their exudates (Olsson and Johnson, 2005; Ostle et al., 2007; Kuzyakov, 2010). In general, our understanding of the short-term transfer of $\mathrm{C}$ between plants and soil biota remains limited, although it is widely recognized that this interaction plays a key role in the $\mathrm{C}$ cycle and soil C sequestration (Ostle et al., 2009b; Bardgett et al., 2009; Paterson et al., 2009).

Vegetation in itself represents a substantial pool of terrestrial C. However, plant taxa can differ strongly in the rate at which they assimilate and lose $\mathrm{C}$ by respiration, exudation and tissue turnover, and hence in their effect on the soil C balance (Dorrepaal, 2007; De Deyn et al., 2008; Paterson et al., 2009). For example, dominance of plants with high $\mathrm{C}$ assimilation rates may not be beneficial for ecosystem $\mathrm{C}$ sequestration if these plants also experience fast rates of $\mathrm{C}$ loss, and/or if they promote the activity of decomposer

Published by Copernicus Publications on behalf of the European Geosciences Union. 
organisms through the inputs of exudates to soil. In contrast, dominance of communities by slow-growing plants can be beneficial for ecosystem $\mathrm{C}$ sequestration because dead tissue of these plants generally decomposes more slowly than that of faster-growing plant species as it is a poor food source for soil microbes.

Living vascular plants provide recent assimilated $\mathrm{C}$ to soil biota via their roots. The primary consumers of this new plant $\mathrm{C}$ are bacteria, mycorrhizal fungi and saprophytic fungi. These groups of soil biota play different roles in $\mathrm{C}$ cycling because of divergence in the speed of assimilation of plant-derived $\mathrm{C}$, their spectrum of $\mathrm{C}$ sources and their average C:N stoichiometry (van der Heijden et al., 2008; De Deyn et al., 2008; Strickland and Rousk, 2010). In particular, mycorrhizal fungi are responsive to plant $\mathrm{C}$ assimilation and allocation to roots because of their symbiotic nature (Johnson et al., 2002; Olsson and Johnson, 2005). More generally, bacteria and fungi may differentially affect $\mathrm{C}$ cycling, so that ecosystem management that promotes fungi over bacteria, such as the cessation of fertiliser application (Bardgett and McAlister, 1999; Smith et al., 2008), is expected to promote soil C sequestration (Six et al., 2006; Strickland and Rousk, 2010).

The rate of assimilation, transfer and retention of recent photosynthetic assimilated $\mathrm{C}$ in ecosystems thus depends on the community composition of plants and/or of soil microbes (Dorrepaal, 2007; Ward et al., 2009; Woodin et al., 2009; Paterson et al., 2009), but also on the activity of the plant and microbial taxa which can be altered by ecosystem management (Treonis et al., 2004; Hill et al., 2007; Denef et al., 2009). In a long-term grassland restoration experiment Smith et al. $(2003,2008)$ showed that cessation of mineral fertiliser use and the seeding of target plant species increased plant species richness and the abundance of soil fungi, compared to soil bacteria. These restoration treatments also enhanced the rate of soil C and $\mathrm{N}$ accumulation (De Deyn et al., 2011), suggesting potential management impacts on short-term $\mathrm{C}$ fluxes through plants and soil biota.

In this study we explored the effects of plant taxa and management treatments aimed at restoring plant species diversity (i.e. cessation of fertilser use and seeding) on the rate of $\mathrm{C}$ assimilation and transfer to soil microbes in a temperate grassland. This was achieved in a long-term diversity manipulation experiment in northern England (Smith et al., 2003, 2008) using an in situ ${ }^{13} \mathrm{C}-\mathrm{CO}_{2}$ pulse-chase labelling technique (Ostle et al., 2003, 2007). We predicted that $\mathrm{C}$ uptake by the plants and transfer of this $\mathrm{C}$ to soil microbes would be faster in fertilised plots and in plants with high growth rates (Ward et al., 2009). We also expected mycorrhizal fungi to show rapid assimilation of plant C (Johnson et al., 2002) but less so in fertilised plots (Bradley et al., 2006; Denef et al., 2009), with the signal of recent plant $C$ remaining longer in fungi than in shorter-lived bacteria (Ostle et al., 2003; Rousk and Baath, 2007).

\section{Material and methods}

\subsection{Experimental design}

Measurements were made in four treatments arranged in three blocks in a long-term (since 1990) multi-factorial grassland restoration experiment (Smith et al., 2008). The study site, Colt Park meadows, is located in north west England in the Ingleborough National Nature Reserve (latitude $54^{\circ} 12^{\prime} \mathrm{N}$, longitude $2^{\circ} 21^{\prime} \mathrm{W}$ ) on Lolium perenneCynosorus cristatus grassland. The soil is a shallow brown earth over limestone of moderate-high residual fertility $\left(15 \mathrm{mg} \mathrm{P}_{2} \mathrm{O}_{2} \mathrm{~L}^{-1}\right)$, with $19 \%$ organic matter and $\mathrm{C} \%$ of 7.7 and $\mathrm{N} \%$ of 0.75 and average $\mathrm{pH}$ of 5.5. All plots were grazed in autumn and spring and cut for hay on 21 July since 1999. We selected treatments which have had the most significant impact on vegetation composition with the greatest increases in plant species diversity: i.e. the cessation of NPK fertiliser application and the addition of seed mixtures (of Ranunculus bulbosus, Lotus corniculatus, Briza media and Geranium sylvaticum), and their full factorial combinations (i.e. stopping fertiliser application without seed addition, stopping fertiliser application with seed addition, continued fertiliser application with seed addition, and continued fertiliser application without seed addition). Fertiliser addition was done yearly in early May (25 kg N and $12.5 \mathrm{~kg}$ P and K per ha) (Smith et al., 2003, 2008). The in situ pulse-labelling was performed simultaneously in 12 plots, which correspond with the plots that did not receive seeding with Trifolium pratense in the study on soil C sequestration by De Deyn et al. (2011). The identity and $\%$ cover of vascular plant species in the central $2 \times 2 \mathrm{~m}$ of each plot was determined in June 2006 according to Stace (1991). The vegetation characteristics across these plots per treatment are shown in Table 1.

\section{$2.2{ }^{13} \mathrm{CO}_{2}$ pulse labelling and ${ }^{13} \mathrm{C}$ enrichment in vegetation and soil microbes}

To investigate the fate of recently plant assimilated $\mathrm{C}$ in plant and soil microbes a ${ }^{13} \mathrm{CO}_{2}$ pulse-chase assay was performed according to the method of Ostle et al. (2003). In brief, in each treatment plot vegetation was exposed to air in which ambient $\mathrm{CO}_{2}$ was replaced by ${ }^{13} \mathrm{C}$ labelled $\mathrm{CO}_{2}(99$ atom $\%$ ${ }^{13} \mathrm{C}$ enriched) at $370 \mathrm{ppm}$ within a transparent acrylic chamber $\left(40 \mathrm{~cm}\right.$ diameter, $20 \mathrm{~cm}$ height; $\left.1257 \mathrm{~cm}^{2}\right)$ at flow rates of 6 liters per minute and maintained for 6 daylight hours on 31 August 2006.

Plant and soil samplings were made immediately before ${ }^{13} \mathrm{CO}_{2}$ labelling and 2, 24 and $48 \mathrm{~h}$, and 1 and 3 weeks after labelling. At each sampling, shoot material from each of six different species within the chamber were sampled. The selected species were common grass, forb, legume and moss species across the treatments: Anthoxanthum odoratum and Festuca rubra (grasses), Ranunculus repens and Rumex 
Table 1. Plant species richness (per $4 \mathrm{~m}^{2}$ ) and abundance cover $(\%)$ of vascular plant species in relation to restoration management treatments. Management treatments are: $C=$ no seed, no fertiliser; $S=$ with seed, no fertiliser; $F=$ no seed, with fertiliser; SF $=$ with seed, with fertiliser. Values are means $\pm 1 \mathrm{SE}(N=3)$, no number indicates absence of the species, SE of species abundance cover not included because many species occurred in only one plot.

\begin{tabular}{lcccc}
\hline & \multicolumn{4}{c}{ Management treatment } \\
\hline & $C$ & $S$ & $F$ & SF \\
\hline Average species richness & $19.7 \pm 1.8$ & $22 \pm 2.1$ & $16.7 \pm 0.3$ & $23.3 \pm 3.3$ \\
Agrostis capillaris & 18.3 & 21.7 & 20.0 & 21.7 \\
Anthoxanthum odoratum & 12.7 & 16.7 & 16.7 & 23.3 \\
Festuca rubra & 5.0 & 6.7 & 13.3 & 13.3 \\
Rumex acetosa & 5.0 & 3.3 & 13.3 & 5.3 \\
Ranunculus acris & 28.3 & 18.3 & 11.7 & 16.7 \\
Lolium perenne & 5.7 & 10.0 & 10.0 & 5.3 \\
Ranunculus repens & 16.7 & 15.0 & 9.3 & 4.7 \\
Holcus lanatus & 2.7 & 1.0 & 3.3 & 3.7 \\
Poa trivialis & 2.7 & 0.3 & 3.0 & 2.3 \\
Rhinantus minor & 1.0 & 1.0 & 1.0 & 1.7 \\
Trifolium repens & 2.0 & 1.7 & 1.0 & 0.7 \\
Bellis perennis & 0.7 & 0.7 & 0.7 & 0.7 \\
remaining other species & 10.3 & 16.0 & 5.0 & 14.0 \\
\hline
\end{tabular}

acetosa (forbs), Trifolium repens (legume) and Brachythesium rutabulum (moss). Vegetation was sampled by snipping $2 \mathrm{~cm}$ long leaf tips of young undamaged leaves, a leaflet of 3 sub-leaves for Trifolium repens, and the top $2 \mathrm{~cm}$ of green bryophyte Brachythesium rutabulum. Samples were put in individual eppendorf tubes and immediately frozen at $-20^{\circ} \mathrm{C}$. Soil samples were collected by taking a single core $(3.4 \mathrm{~cm}$ diameter, $10 \mathrm{~cm}$ deep), from which subsamples were collected from the soil layer at 3 to $5 \mathrm{~cm}$ depth to standardise sampling. Soil cores and vegetation samples were taken such that at each sampling time a different quarter from within the labelled areas was used. All plant species sampled were present in all quarters of the labelled area, but the plant species were so intermixed that it was not possible to quantify their belowground abundances in the soil cores. Roots were removed from the soil samples with tweezers and root-free soil was immediately frozen and freeze-dried. The coring holes were refilled immediately with soil cores from the same plot, but from outside the pulse chamber. Enrichment of ${ }^{13} \mathrm{C}$ in plant aboveground tissues was determined using freeze-dried and finely ground plant material. This was weighed into tin cups, and the samples were analysed for total $\mathrm{C}$ and ${ }^{13} \mathrm{C} /{ }^{12} \mathrm{C}$ isotopic ratio using a Flash EA 1112 Series elemental analyser (Thermo Electron Corporation, Bremen, Germany) coupled with a Delta ${ }^{\text {plus }}$ Advantage isotope ratio mass spectrometer (IRMS, Thermo Finnigan, Bremen, Germany). We expressed enrichment of ${ }^{13} \mathrm{C}$ in plants as ${ }^{13} \mathrm{C}$ atom $\%$ excess with atom $\%$ excess $=$ atom $\%$ enriched sample - atom $\%$ background sample (i.e. before labelling $)$, in which atom $\%=\left[R_{\text {sample }} /\left(R_{\text {sample }}+1\right)\right] \times 100$ and $R_{\text {sample }}={ }^{13} \mathrm{C} /{ }^{12} \mathrm{C}$ ratio measured by IRMS (Leake et al., 2006). Phosopholipid fatty acid (PLFA) markers in soils from samplings 2, 24, $48 \mathrm{~h}$ in 1 week were extracted from freeze-dried ground soil using the protocol described in Bardgett et al. (1996) and were quantified using quantitative gas chromatography (GC Combustion III, Thermo Finnigan) and corrected for the $\mathrm{C}$ added during derivatisation. Individual PLFAs were separated by using a Trace Ultra GC (Thermo Finnigan, Bremen, Germany) with a J\&W DB-5 capillary GC column $(60 \mathrm{~m} \times 0.25 \mathrm{~mm}$ id $\times 0.25 \mu \mathrm{m}$ film thickness; Agilent Technologies Ltd, Berkshire, UK), and their identification was based on retention times as compared to those of known standards (Supelco, Supelco UK, Poole, Dorset, UK). To determine the ${ }^{13} \mathrm{C} /{ }^{12} \mathrm{C}$ isotopic ratio of individual PLFAs the extracts were measured on a GC-C-IRMS (Thermo Finnigan, Bremen, Germany). Isotopic enrichment in PLFAs was expressed as $\delta^{13} \mathrm{C}$ values, with $\delta^{13} \mathrm{C}(\%)=\left[\left(R_{\text {sample }}-R_{\text {reference }}\right) /\left(R_{\text {reference }}\right)\right] \times 10^{3}$ where $R_{\text {reference }}$ is the ${ }^{13} \mathrm{C} /{ }^{12} \mathrm{C}$ ratio of reference material calibrated to the Vienna Pee Dee Belemnite scale. The PLFA 16:1 $\omega 5$ was used as an indicator of AMF abundance (Olsson, 1999); 18:2 $\omega 6,9$ and 18:1 $\omega 9$ were used as markers for saprophytic fungi; 10Me18:0 was used for actinomycetes; 16:1 $17 \mathrm{c}, 18: 1 \omega 7$ and 19:0cy were used as markers for Gramnegative bacteria; and C15:0i and C15:0ai were used for Gram-positive bacteria (Patra et al., 2008). 


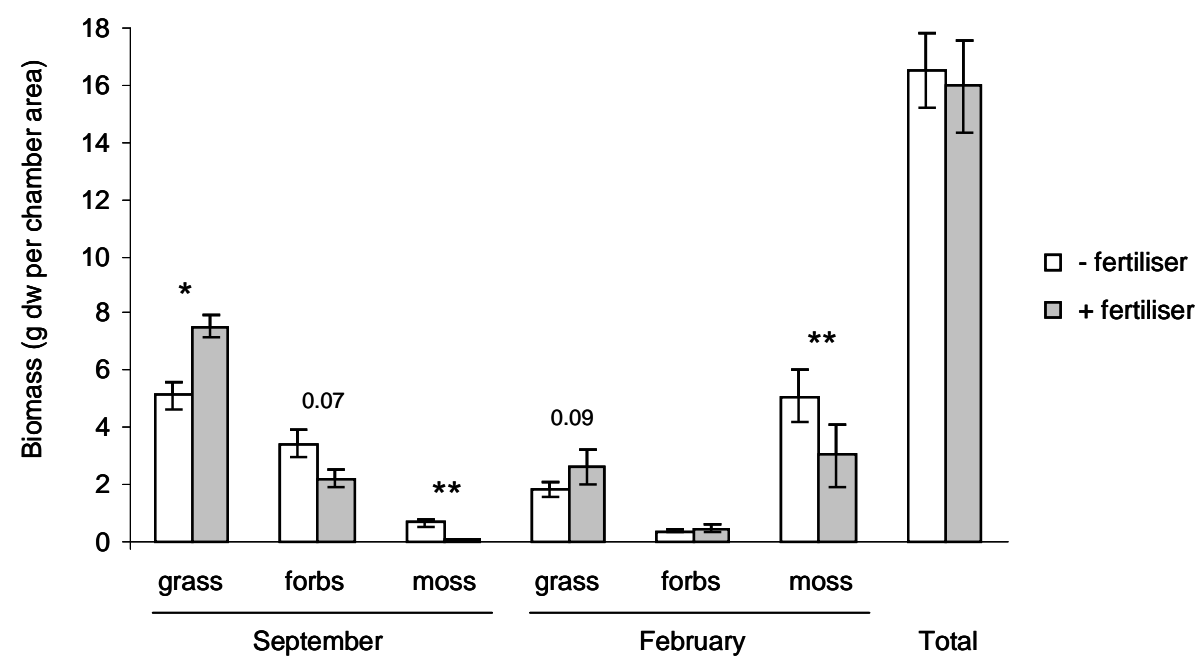

Fig. 1. Distribution of aboveground biomass over different plant groups in September and February in relation to fertiliser treatments. Values are means $\pm 1 \mathrm{SE}$, significant differences between fertiliser treatments: $* P<0.05, * * P<0.01$.

\subsection{Plant biomass}

Plant community total biomass and the standing biomass of grasses, forbs, legumes and mosses in the area of each labelling chamber was determined by clipping the vegetation $1 \mathrm{~cm}$ above the soil surface 3 weeks after the pulse (21 September). Vegetation was sorted, dried for $48 \mathrm{~h}$ at $70{ }^{\circ} \mathrm{C}$, and weighed. Vegetation was sampled again in a similar way in February.

\subsection{Data analysis}

The effect of management treatments (i.e. fertiliser use and seeding) and time since the pulse on ${ }^{13} \mathrm{C}$ enrichment in plant tissue (or in signature PLFAs) was tested per plant species (or per signature PLFA) across sampling times using Repeated Measures ANOVA with time as repeat, fertiliser use, seeding and their interaction as fixed factors and block as a random factor. The effect of plant species identity (or PLFA identity) on ${ }^{13} \mathrm{C}$ enrichment in plant tissue (or in signature PLFA) was tested per sampling time. For the samples collected 2 and $24 \mathrm{~h}$ and 1 week after the ${ }^{13} \mathrm{C}-\mathrm{CO}_{2}$ pulse we used General Linear Models (GLM) with fertiliser use, seeding, plant species (or signature PLFAs) and their interactions as fixed factors and block as a random factor. Enrichment in plant tissue collected $48 \mathrm{~h}$ and 3 weeks after the pulse was analysed using non-parametric Kruskal-Wallis ANOVA with plant species as predicting factor, because of unequal variances between plant species. Restoration management effects on the total dry weight of the plant community in September and February was tested by GLM with fertiliser use, seeding, and their interaction as fixed factors and block as a random factor. Treatment effects on the dry weights of the different plant groups (grasses, forbs including legumes and moss) in September and February were tested using repeated measures ANOVA with plant group as repeat and with the aforementioned predictor variables. Management effects on the abundance of total bacteria, fungi and mycorrhiza PLFA were tested across sampling times using multivariate MANOVA. Differences between levels of significant factors were tested using Tukey HSD (parametric) and Mann-Whitney U (non-parametric) post-hoc tests. Enrichment values were $\log (1+x)$ transformed prior to analysis in order to obtain equal variances between species.

\section{Results}

\subsection{Management effects on plant biomass and C flux}

Total standing plant biomass in September and February did not differ across management treatments of seeding $\left(F_{1,6}=0.18, P>0.05\right)$ or fertiliser use $\left(F_{1,6}=0.29, P>\right.$ 0.05) (Fig. 1), but the biomass produced by each plant group was markedly affected (interaction fertiliser use $x$ plant group September: $F_{2,12}=10.18, P=0.003$; February: $\left.F_{2,12}=18.28, P<0.001\right)$. Moss biomass was promoted in the absence of mineral fertiliser (September: $F_{1,6}=25.35$, $P=0.002$; February: $\left.F_{1,6}=13.77, P=0.01\right)$ and contributed most to the dry weight of the plant community in the February winter sampling (Fig. 1).

Overall, management treatments had no significant effect on the ${ }^{13} \mathrm{C}$ enrichment of the different plant species at any sampling time (Fig. 2). However, across treatments, consistent differences in ${ }^{13} \mathrm{C}$ enrichment between plant species were detected. Two hours after the ${ }^{13} \mathrm{C}-\mathrm{CO}_{2}$ pulse all plants showed significant ${ }^{13} \mathrm{C}$ enrichment in their aboveground tissues, but ${ }^{13} \mathrm{C}$ enrichment was significantly higher 


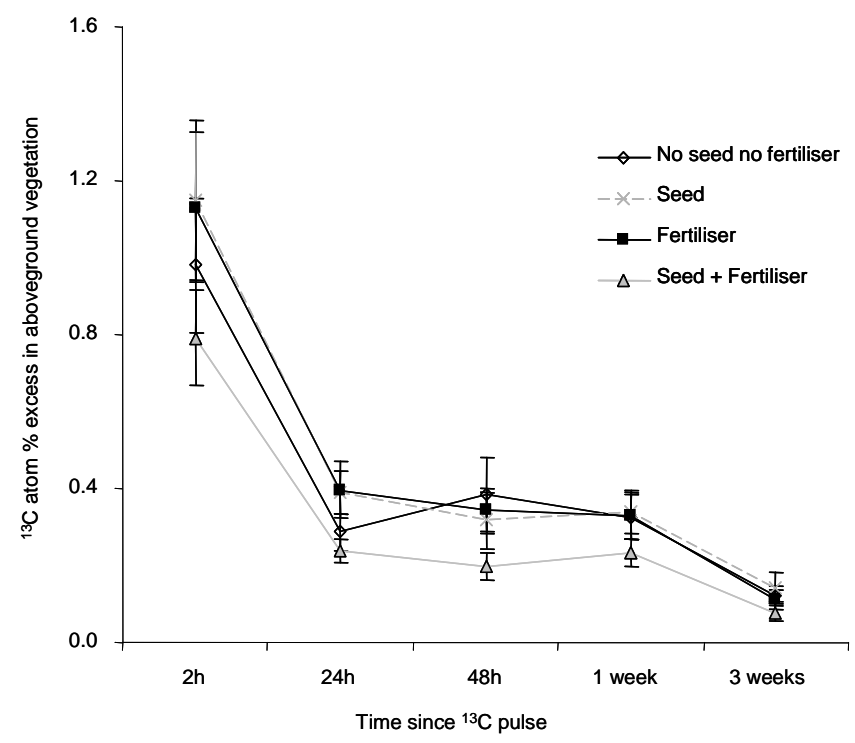

Fig. 2. ${ }^{13} \mathrm{C}$ atom $\%$ excess in leaf tissue across species in relation to restoration management over a 21 -day ${ }^{13} \mathrm{CO}_{2}$ pulse-chase period. Management treatments are: no seed, no fertiliser; with seed, no fertiliser; no seed, with fertiliser; with seed, with fertiliser. Values are means $\pm 1 \mathrm{SE}(N=3)$.

$\left(F_{5,44}=17.01, P<0.001\right)$ in vascular plants than in moss (Fig. 3). Across vascular plant species, $R$. repens showed the highest, $R$. acetosa and the legume species T. repens the lowest, and A. odoratum and F. rubra intermediate levels of ${ }^{13} \mathrm{C}$ enrichment across all treatments. By $24 \mathrm{~h}$ after the pulse labelling, ${ }^{13} \mathrm{C}$ enrichment in aboveground tissue had strongly declined in all vascular plant species, but there was still a significant effect of plant species $\left(F_{5,44}=2.94, P<0.05\right)$ due to higher ${ }^{13} \mathrm{C}$ enrichment in $R$. repens than in moss across all treatments. Also, after $48 \mathrm{~h}\left(\mathrm{KW} H_{5, n=71}=12.70, P<0.05\right)$ and 1 week $\left(F_{5,44}=3.28, P<0.05\right)$ there was a plant species effect on ${ }^{13} \mathrm{C}$ enrichment: $R$. repens remained more enriched than moss and $F$. rubra after $48 \mathrm{~h}$, and than moss 1 week after the pulse. Three weeks after the pulse labelling, there was no longer a plant species effect on the levels of ${ }^{13} \mathrm{C}$ enrichment (KW $H_{5, n=71}=8.94, P=0.11$ ) (Fig. 3).

\subsection{Photosynthate $\mathrm{C}$ flux through soil microbes}

Management treatments did not affect ${ }^{13} \mathrm{C}$ enrichment in any of the PLFAs, while time since pulse labelling strongly affected enrichment in all but the actinomycete specific PLFA 10Me18:0 (Table 2). All signature PLFAs were most enriched (i.e. showed the largest content of recently assimilated plant ${ }^{13} \mathrm{C}$ ) $24 \mathrm{~h}$ after pulse labelling (Fig. 4). Across signature PLFAs, 16:1 $\omega 5$ (AMF) and 18:2 $\omega 6,9$ (saprophytic fungi) showed the largest incorporation of recent plant derived ${ }^{13} \mathrm{C}$ between 2 and $24 \mathrm{~h}$ after the pulse. At $48 \mathrm{~h}$ after labelling, ${ }^{13} \mathrm{C}$ enrichment was comparable to that at $24 \mathrm{~h}$ for most PLFAs, but was significantly reduced in the 18:1 $\omega 9$

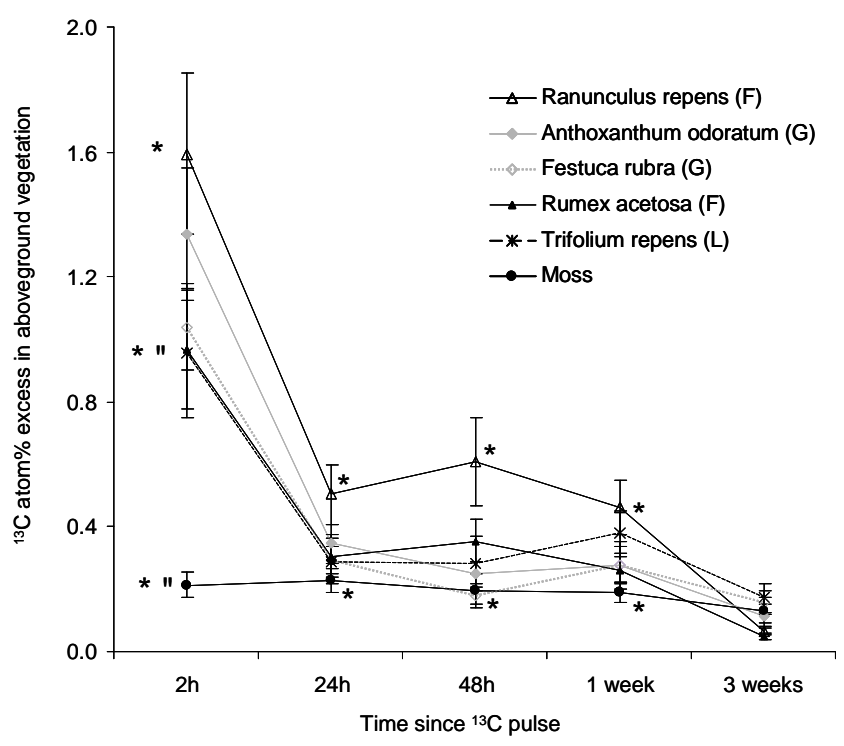

Fig. 3. ${ }^{13} \mathrm{C}$ atom $\%$ excess in leaf tissue from co-occurring species in mixed grassland (two forb $F$, two grass $G$, one legume $L$ and a moss species) over a 21 -day ${ }^{13} \mathrm{CO}_{2}$ pulse-chase period. Values are means and means sharing the same symbol are significantly different at the respective time after labelling $(P<0.05 ; N=12)$.

fungal PLFA. One week after the pulse, ${ }^{13} \mathrm{C}$ enrichment in PLFAs had declined to similar levels as at $2 \mathrm{~h}$ after pulse labelling the vegetation, except for the fungal PLFA 18:2 $\omega 6,9$ which showed significantly higher enrichment then all other PLFAs $\left(F_{7,42}=32.74, P<0.0001\right)$. Restoration management had no effect on the average abundances of soil bacteria, fungi, actinomycetes and AMF across the pulse-chase sampling campaign (fertiliser $F_{1,42}=0.46, P=0.50$; seed addition $F_{1,42}=0.10, P=0.76$ ), but abundances were distinct between the groups of soil microbes (Wilks Lambda $\left.F_{3,40}=400.9, P<0.0001\right)$. Generally bacteria dominated the microbial biomass in all treatments (average PLFA biomass $49.4 \pm 1.7 \mu \mathrm{g}$ per $\mathrm{g}$ soil $\mathrm{dw}$ ) and saprophytic fungi were the second (average PLFA biomass $10.1 \pm 0.4 \mu \mathrm{g}$ per $\mathrm{g}$ soil $\mathrm{dw}$ ) and AMF third (average PLFA biomass $3.5 \pm 0.1 \mu \mathrm{g}$ per g soil dw) most abundant group of soil microbes.

\section{Discussion}

\subsection{Species and management effects on $\mathrm{C}$ flux}

Overall our results support the hypothesis that in speciesrich grassland, plant species differ markedly in the rate of assimilation and potentially also of translocation of recently photosynthesised $\mathrm{C}$ to soil. In line with studies in peatland and arctic systems, we found that mosses assimilated $\mathrm{C}$ at a much slower rate, but retained the ${ }^{13} \mathrm{C}$ signal longer in their tissues than did vascular plants (Dorrepaal, 2007; Woodin et al., 2009; Ward et al., 2009). Within the vascular plants 
Table 2. Repeated measures ANOVA results across sampling time (R1) for ${ }^{13} \mathrm{C}$ enrichment in soil microbial PLFAs as affected by restoration management treatments (seed addition $S$, fertiliser use $F$, and their interaction $S \times F$ ). Results of interactions between restoration factors and $R 1$ and of block not shown as none were significant, apart from a small block effect for PLFA 18:2 $\omega 6,9$ $\left(F_{2,5}=10.97, P<0.05\right)$. Statistical significant factors in bold.

\begin{tabular}{|c|c|c|c|c|}
\hline PLFA & Factor & $F$ & $d f$ & $P$ \\
\hline \multirow[t]{4}{*}{$16: 1 \omega 5$} & $S$ & 0.00 & 1,6 & 0.99 \\
\hline & $F$ & 0.74 & 1,6 & 0.42 \\
\hline & $S \times F$ & 1.06 & 1,6 & 0.34 \\
\hline & $R \mathbf{1}$ & 19.63 & 3,18 & $<\mathbf{0 . 0 0 0 1}$ \\
\hline \multirow[t]{4}{*}{$18: 2 \omega 6,9$} & $S$ & 0.06 & 1,5 & 0.82 \\
\hline & $F$ & 0.55 & 1,5 & 0.49 \\
\hline & $S \times F$ & 2.45 & 1,5 & 0.18 \\
\hline & $R \mathbf{1}$ & 11.05 & 3,15 & $<0.001$ \\
\hline \multirow[t]{4}{*}{$18: 1 \omega 9$} & $S$ & 0.26 & 1,5 & 0.63 \\
\hline & $F$ & 0.23 & 1,5 & 0.65 \\
\hline & $S \times F$ & 4.35 & 1,5 & 0.09 \\
\hline & $R \mathbf{1}$ & 24.44 & 3,15 & $<0.0001$ \\
\hline \multirow{4}{*}{$18: 1 \omega 7$} & $S$ & 0.42 & 1,6 & 0.54 \\
\hline & $F$ & 1.69 & 1,6 & 0.24 \\
\hline & $S \times F$ & 3.15 & 1,6 & 0.13 \\
\hline & $R \mathbf{1}$ & 27.00 & 2,12 & $<\mathbf{0 . 0 0 0 1}$ \\
\hline \multirow[t]{4}{*}{ 19:0cy } & $S$ & 0.02 & 1,6 & 0.89 \\
\hline & $F$ & 0.45 & 1,6 & 0.53 \\
\hline & $S \times F$ & 0.75 & 1,6 & 0.42 \\
\hline & $R 1$ & 193.1 & 3,18 & $<\mathbf{0 . 0 0 0 1}$ \\
\hline \multirow[t]{4}{*}{$16: 1 \omega 7 \mathrm{c}$} & $S$ & 2.42 & 1,5 & 0.18 \\
\hline & $F$ & 0.51 & 1,5 & 0.51 \\
\hline & $S \times F$ & 0.43 & 1,5 & 0.54 \\
\hline & $R \mathbf{1}$ & 44.43 & 3,15 & $<\mathbf{0 . 0 0 0 1}$ \\
\hline \multirow[t]{4}{*}{ i15:0 } & $S$ & 0.24 & 1,6 & 0.64 \\
\hline & $F$ & 0.00 & 1,6 & 0.97 \\
\hline & $S \times F$ & 0.31 & 1,6 & 0.60 \\
\hline & $R \mathbf{1}$ & 59.39 & 3,18 & $<\mathbf{0 . 0 0 0 1}$ \\
\hline \multirow[t]{4}{*}{ a15:0 } & $S$ & 7.36 & 1,6 & 0.035 \\
\hline & $F$ & 0.02 & 1,6 & 0.90 \\
\hline & $S \times F$ & 0.22 & 1,6 & 0.66 \\
\hline & $R \mathbf{1}$ & 59.55 & 3,18 & $<\mathbf{0 . 0 0 0 1}$ \\
\hline \multirow[t]{4}{*}{ 10Me18:0 } & $S$ & 0.56 & 1,5 & 0.47 \\
\hline & $F$ & 0.17 & 1,5 & 0.70 \\
\hline & $S \times F$ & 1.54 & 1,5 & 0.27 \\
\hline & $R \mathbf{1}$ & 2.66 & 3,15 & 0.09 \\
\hline
\end{tabular}

forbs did not behave differently from grasses, but rather behaved in a species-specific way: $R$. repens showed the highest initial C assimilation rate and $R$. acetos $a$ and T. repens the lowest. This indicates that using a priori defined functional groups of grasses, forbs and legumes may not be the best way of aggregating plant groups in relation to short-term $\mathrm{C} \mathrm{cy-}$ cling, supporting the suggestions of Wright et al. (2006) for the relationships between plant diversity and above-ground and below-ground biomass production. Instead of focusing
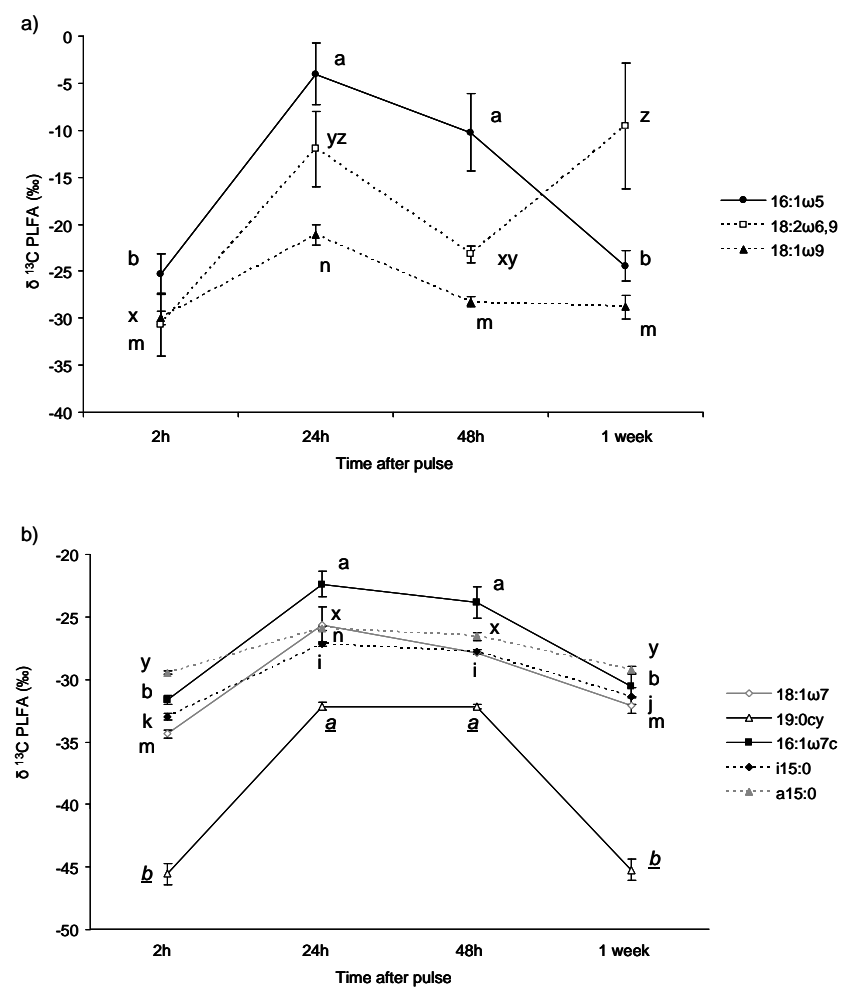

Fig. 4. ${ }^{13} \mathrm{C}$ enrichment over a 1 -week ${ }^{13} \mathrm{CO}_{2}$ pulse-chase period in (a) fungal PLFAs and b) bacterial PLFAs. Values are means $\pm 1 \mathrm{SE}$ and means of the same PLFA not sharing the same letter are significantly different between the respective times $(P<0.05 ; N=12)$. Solid line indicates AMF (a) or gram negative bacteria (b), dotted line indicate saprophytic fungi (a) or gram positive bacteria (b).

on pre-defined functional groups, future studies could benefit from taking a trait-based approach, using measurable characteristics of the different components of communities (across trophic levels) rather than categorical groups, as has recently become the focus in biodiversity-ecosystem functioning research (De Deyn et al., 2008; Hillebrand and Matthiessen, 2009; Reiss et al., 2009). In contrast to our expectation, under the assumption of overall increased plant photosynthetic activity with fertilisation given higher productivity (De Deyn et al., 2011), we did not find effects of fertiliser application on the $\mathrm{C}$ uptake and transfer to microbes. However, our results are in line with the study of Hill et al. (2007) where mineral $\mathrm{N}$ application also did not affect $\mathrm{C}$ assimilation rates in Lolium perenne, as opposed to the strong effect of elevated $\mathrm{CO}_{2}$ levels. In their recent review Kuzyakov and Gavrichkova (2010) also indicate that ambient $\mathrm{CO}_{2}$ concentration, temperature and photosynthetic active radiation rather then soil nutrient availability drive photosynthetic $\mathrm{C}$ assimilation. Overall it appears that the short-term assimilation and transfer of $\mathrm{C}$ by the vegetation were not influenced by restoration management practices. 
In line with our expectation, ${ }^{13} \mathrm{C}$ enrichment of soil microbes was rapid and peaked $24 \mathrm{~h}$ after the pulse for AMF, but also in decomposer soil fungi and in gram negative and gram positive soil bacteria. The fast allocation of recent plant assimilated $\mathrm{C}$ to AMF and saprophytic soil fungi and the poor response of actinomycetes is in line with previous studies (Johnson et al., 2002; Treonis et al., 2004; Denef et al., 2009). However, we did not find a time lag between the response of saprophytic fungi and bacteria (Olsson and Johnson, 2005; Denef et al., 2007). Although ${ }^{13} \mathrm{C}$ enrichment in fungi and bacteria initially peaked at similar sampling times, with the enrichment being particularly high in AMF, 1 week after the pulse enrichment remained specifically high in saprophytic fungi, indicating longer retention times in this group of soil microbes, as was found by Treonis et al. (2004). This result could be explained by the generally longer lifespan of fungi as opposed to bacteria (Ostle et al., 2003; Rousk and Baath, 2007), but it is less clear why the signal declined as quickly in AMF; perhaps selective grazing by fungal-feeding soil fauna (Johnson et al., 2005) or relative large loss of $\mathrm{C}$ from AMF via $\mathrm{C}$ rich excretions (Johnson et al., 2002; Rillig, 2004) played a role. Moreover it may well be that the ${ }^{13} \mathrm{C}$ signal in AMF became rapidly diluted by the inflow of unlabeled fresh $\mathrm{C}$ via the plant roots soon after the ${ }^{13} \mathrm{C}$ pulse. In contrast, the high levels of ${ }^{13} \mathrm{C}$ in the saprophytic fungi one week after the pulse could in part be due to recycling of ${ }^{13} \mathrm{C}$ released by other soil biota upon their death. It is notable that the ${ }^{13} \mathrm{C}$ signature in the PLFA 18:1 $\omega 9$, which is often used as fungal PLFA (Treonis et al., 2004; Chung et al., 2007; Denef et al., 2009), showed a pattern more alike that found in bacteria than in the other PLFA indicative for saprophytic fungi. This result may be due to the fact that the PLFA $18: 1 \omega 9$ is also found in bacteria (Zelles, 1997).

Management treatments of fertiliser application have been shown to suppress the allocation of recent photosynthetic $\mathrm{C}$ to AMF, and more generally to all fungal PLFA biomarkers (Bradley et al., 2006; Denef et al., 2009). In our study we did not find such a response as ${ }^{13} \mathrm{C}$ enrichment in soil microbial PLFAs were consistent across management treatments. The reason why we did not find effects of fertiliser use on ${ }^{13} \mathrm{C}$ enrichment may due to the time elapsed since application fertiliser application in May with pulse labelling last day of August, and the modest addition rate $\left(25 \mathrm{~kg} \mathrm{ha}^{-1} 20: 10: 10\right.$ $\mathrm{N}: \mathrm{P}: \mathrm{K})$ of the fertiliser. In the aforementioned studies of Bradley et al. (2006) and Denef et al. (2009) the levels of $\mathrm{N}$ applications that did cause significant shifts in soil PLFA abundances, irrespective of time since application, and their signature of new photosynthate-C were much higher: ranging from 225 to $450 \mathrm{~kg} \mathrm{~N} / \mathrm{ha} / \mathrm{yr}$, suggesting that the responses might also be strongly dose dependent.

\subsection{Indirect management effects on $\mathrm{C}$ flux and storage}

Restoration management treatments significantly affected the biomass of the different plant groups. Specifically the cessation of fertiliser use promoted moss and forbs and reduced grass biomass, but in such a way that total aboveground biomass was not affected. Given the slow rate of $\mathrm{C}$ respiration in moss rich vegetation and their high $\mathrm{C}: \mathrm{N}$ ratio (Ward et al., 2007), this shift in vegetation composition has the potential to enhance $C$ sequestration in vegetation in unfertilised treatments (De Deyn et al., 2011). These results also indicate that mosses might play a key role in the sequestration of $\mathrm{C}$ in grasslands, especially during times when vascular plant growth ceases, as is typically the case in autumn to early spring. Given that we found higher concentrations of ${ }^{13} \mathrm{C}$ in soil fungi than bacteria which remained high one week after the pulse our results also suggests that grassland management that promotes soil fungi over bacteria could promote the retention of recent plant assimilate $C$ in soil. Smith et al. $(2003,2008)$ showed that this can be achieved by ceasing fertiliser use and by the promotion of specific plant species by seeding. The studies of Smith et al. $(2003,2008)$ were performed at the same experimental site, including the plots we used in the current study. Therefore, it is rather surprising that we did not find significant differences in PLFA abundances across management treatments. However, this discrepancy could be due to differences in the time of sampling between studies: Smith et al. $(2003,2008)$ sampled in July, while we sampled in September, and PLFA abundances, and especially those of fungi, are known to be very responsive to seasonality being most abundant in spring and least in autumn (Bardgett et al., 1999). Moreover, the direction and magnitude of effects of grassland management treatments on soil microbial communities, measured using PLFA, are known to vary across seasons (Bardgett et al., 1999), and may be attributed in part to the length of time since fertiliser has been applied. In our study, the longer recovery time for fungi, who tend to decline rapidly in response to fertiliser $\mathrm{N}$ application which is done at our site in May (Donnison et al., 2000a, b; Smith et al., 2003, 2008), may have resulted in similar PLFA abundances of the soil microbes across treatments.

The net effect of changes in grassland management on ecosystem $\mathrm{C}$ storage is ultimately dependent on the longerterm balance between $\mathrm{C}$-influx via photosynthesis and $\mathrm{C}$ release. This balance can not be directly be predicted from short-term $\mathrm{C}$ flows and standing biomass, as most $\mathrm{C}$ in grasslands is in the form of non-living soil organic $\mathrm{C}$ which is mostly plant-derived and has been processed by soil microbes to varying degrees. In the current study, we found that $\mathrm{C}$ flow of recent photosynthate was not altered by management practices of mineral fertiliser use or seeding, while in another study we did find significant impacts of these longterm treatments on soil $\mathrm{C}$ and $\mathrm{N}$ sequestration (De Deyn et al., 2011). In the latter study, using the same field site, but 
including one additional treatment (i.e. seeding of the legume species Trifolium pratense), we found that the cessation of mineral fertiliser use significantly increased soil $\mathrm{C}$ and $\mathrm{N}$ sequestration, but especially when combined with seeding of T. pratense which stimulated biological $\mathrm{N}$ influx, reduced activities of key enzymes involved in recalcitrant organic matter degradation and changed soil structure.

Although we did not detect management effects in our study, we do clearly demonstrate the tight temporal linkage of $\mathrm{C}$ transfer between plants and microbes in grasslands, showing that the activity of many soil microbes is tightly linked to the photosynthetic activity of plants. Given that these soil microbes are regulators of the release of plant available $\mathrm{N}$ from recalcitrant soil organic matter (SOM), such synchronisation of plant and soil microbial activities will likely promote the retention of nutrients in the system, as demonstrated by the low amount of $\mathrm{N}$ leached from extensively managed grasslands (Di and Cameron, 2002; Fontaine et al., 2011). This high retention of nutrients in grasslands could then promote SOM accumulation and $\mathrm{C}$ sequestration over time.

\section{Conclusions}

Overall we found large differences in assimilation of ${ }^{13} \mathrm{C}$ between grassland plants, irrespective of long-term plant diversity restoration management treatments. Vascular and non-vascular plants showed most divergent responses, while responses of vascular plants were not linked to a priori 'functional groups' of grasses and forbs. Plant derived ${ }^{13} \mathrm{C}$ was rapidly and mostly transferred to AMF and saprophytic fungi, but saprophytic fungi showed the signature of the fresh $\mathrm{C}$ longest. Plant diversity restoration management did not directly affect the $\mathrm{C}$ assimilation and transfer amongst plant taxa or groups of soil microbes, but can impact the fate of recent $\mathrm{C}$ by changing their abundances. Together, our findings suggests that the rapid assimilation, turnover and transfer of $\mathrm{C}$ from plants to microbes is common across plant species and that this short-term $\mathrm{C}$ cycling is unaffected by management change at least for low levels of fertiliser application.

Acknowledgements. This project was funded by a grant from the UK Biotechnology and Biological Sciences Research Council (BBSRC) Agri-Food Committee, lead by RDB. GBDD was in part supported by ALW grant 865.05.002. The set-up and maintenance of the field experiments were funded by the UK Department for Environment, Food and Rural Affairs (Defra), as part of the species-rich grassland research programme, and the DIGFOR project led by RDB. We are grateful to Richard Brand-Hardy and Val Brown for supporting us in this programme. We thank Niall P. McNamara and Will Mallot for help with pulse-labelling at the field site, Roger Smith (Newcastle University) for establishing the biodiversity restoration experiment at Colt Park, and Paul Evans (Natural England) for maintaining the field site.

Edited by: M. Bahn

\section{References}

Bardgett, R. D., Hobbs, P. J., and Frostegård, A.: Changes in soil fungal:bacterial biomass ratios following reductions in the intensity of management of an upland grassland, Biol. Fertil. Soils, 22, 261-264, 1996.

Bardgett, R. D. and McAlister, E.: The measurement of soil fungal:bacterial biomass ratios as an indicator of ecosystem selfregulation in temperate meadow grasslands, Biol. Fertil. Soils, 29, 282-290, 1999.

Bardgett, R. D., De Deyn, G. B., and Ostle, N. J.: Plant-soil interactions and the carbon cycle, J. Ecol., 97, 838-839, 2009.

Bradley, K., Drijber, R. A., and Knops, J.: Increased N availability in grassland soils modifies their microbial communities and decreases the abundance of arbuscular mycorrhizal fungi, Soil Biol. Biochem., 38, 1583-1595, 2006.

Chung, H. G., Zak, D. R., Reich, P. B., and Ellsworth, D. S.: Plant species richness, elevated $\mathrm{CO}_{2}$, and atmospheric nitrogen deposition alter soil microbial community composition and function, Glob. Change Biol., 13, 980-989, 2007.

Davidson, E. A. and Janssens, I. A.: Temperature sensitivity of soil carbon decomposition and feedbacks to climate change, Nature, 440, 165-173, 2006.

De Deyn, G. B., Cornelissen, J. H. C., and Bardgett, R. D.: Plant functional traits and soil carbon sequestration in contrasting biomes, Ecol. Lett., 11, 516-531, 2008.

De Deyn, G. B., Shiel, R. S., Ostle, N. J., McNamara, N. P., Oakley, S., Young, I., Freeman, C., Fenner, N., Quirk, H., and Bardgett, R. D.: Additional carbon sequestration benefits of grassland diversity restoration, J. Appl. Ecol., doi:10.1111/j.13652664.2010.01925, in press, 2011.

Denef, K., Bubenheim, H., Lenhart, K., Vermeulen, J., Van Cleemput, O., Boeckx, P., and Müller, C.: Community shifts and carbon translocation within metabolically-active rhizosphere microorganisms in grasslands under elevated $\mathrm{CO}_{2}$, Biogeosciences, 4, 769-779, doi:10.5194/bg-4-769-2007, 2007.

Denef, K., Roobroeck, D., Wadu, M. C. W. M., Lootens, P., and Boeckx, P.: Microbial community composition and rhizodepositcarbon assimilation in differently managed temperate grassland soils, Soil Biol. Biochem., 41, 144-153, 2009.

Di, H. J. and Cameron, K. C.: Nitrate leaching in temperate agroecosystems: sources, factors and mitigating strategies, Nutr. Cycl. Agroecosys., 64, 237-256, 2002.

Donnison, L. M., Griffith, G. S., Hedger, J., Hobbs, P. J., and Bardgett, R. D.: Management influences on soil microbial communities and their function in botanically diverse haymeadows of northern England and Wales, Soil Biol. Biochem., 32, 253-263, 2000a.

Donnison, L. M., Griffith, G. S., and Bardgett, R. D.: Determinants of fungal growth and activity in botanically diverse haymeadows: effects of litter type and fertilizer additions, Soil Biol. Biochem., 32, 289-294, 2000b.

Dorrepaal, E.: Are plant growth-form-based classifications useful in predicting northern ecosystem carbon cycling feedbacks to climate change?, J. Ecol., 95, 1167-1180, 2007.

Fontaine, S. , Henault, C., Aamor, A., Bdioui, N., Bloor, J. M. G., Maire, V., Mary, B., Revaillot, S., and Maron, P. A.: Fungi mediate long term sequestration of carbon and nitrogen in soil through their priming effect, Soil Biol. Biochem., 43, 86-96, 2011.

Hill, P. W., Marshall, C., Williams, G. G., Blum, H., Harmens, H., 
Jones, D. L., and Farrar, J. F.: The fate of photosyntheticallyfixed carbon in Lolium perenne grassland as modified by elevated $\mathrm{CO}_{2}$ and sward management, New Phyt., 173, 766-777, 2007.

Hillebrand, H. and Matthiessen, B.: Biodiversity in a complex world: consolidation and progress in functional biodiversity research, Ecol. Lett., 12, 1405-1419, 2009.

Johnson, D., Leake, J. R., Ostle, N., Ineson, P., and Read, D. J.: In situ $\left(\mathrm{CO}_{2}\right)-\mathrm{C}-13$ pulse-labelling of upland grassland demonstrates a rapid pathway of carbon flux from arbuscular mycorrhizal mycelia to the soil, New Phytol., 153, 327-334, 2002.

Johnson, D., Krsek, M., Wellington, E. M. H., Stott, A. W., Cole, L., Bardgett, R. D., Read, D. J., and Leake, J. R.: Soil invertebrates disrupt carbon flow through fungal networks, Science, 309, p. 1047, 2005.

Kuzyakov, Y.: Priming effects: Interactions between living and dead organic matter, Soil Biol. Biochem., 42, 1363-1371, 2010.

Kuzyakov, Y. and Gavrichkova, O.: Time lag between photosynthesis and carbon dioxide efflux from soil: a review of mechanisms and controls, Glob. Change Biol., 16, 3386-3406, 2010.

Lal, R.: Soil carbon sequestration impacts on global climate change and food security, Science, 304, 1623-1627, 2004.

Leake, J. R., Ostle, N. J., Rangel-Castro, J. I., and Johnson, D.: Carbon fluxes from plants through soil organisms determined by field $\left(\mathrm{CO}_{2}\right)-\mathrm{C}-13$ pulse-labelling in an upland grassland, Appl. Soil Ec., 33, 152-175, 2006.

Olsson, P. A.: Signature fatty acids provide tools for determination of the distribution and interactions of mycorrhizal fungi in soil, FEMS Microbiol. Ecol., 29, 303-310, 1999.

Olsson, P. A. and Johnson, N. C.: Tracking carbon from the atmosphere to the rhizosphere, Ecol. Lett., 8, 1264-1270, 2005.

Ostle, N., Whiteley, A. S., Bailey, M. J., Sleep, D., Ineson, P., and Manefield, M.: Active microbial RNA turnover in a grassland soil estimated using a ${ }^{13} \mathrm{CO}_{2}$ spike, Soil Biol. Biochem., 35, 877-885, 2003.

Ostle, N., Briones, M. J. I., Ineson, P., Cole, L., Staddon, P., and Sleep, D.: Isotopic detection of recent photosynthate carbon flow into grassland rhizosphere fauna, Soil Biol. Biochem., 39, 768777, 2007.

Ostle, N. J., Levy, P. E., Evans, C. D., and Smith, P.: UK land use and soil carbon sequestration, Land Use Policy, 26, 274-283, 2009a.

Ostle, N. J., Smith, P., Fisher, R., Woodward, F. I., Fisher, J. B., Smith, J. U., Galbraith, D., Levy, P., Meir, P., McNamara, N. P., and Bardgett, R. D.: Integrating plant-soil interactions into global carbon cycle models, J. Ecol., 97, 851-863, 2009b.

Paterson, E., Midwood, A. J., and Millard, P.: Through the eye of the needle: a review of isotope approaches to quantify microbial processes mediating soil carbon balance, New Phytol., 184, 1933, 2009.

Patra, A. K., Le Roux, X., Grayston, S. J., Loiseau, P., and Louault, F.: Unraveling the effects of management regime and plant species on soil organic carbon and microbial phospholipid fatty acid profiles in grassland soils, Biores. Technol., 99, 3545-3551, 2008.

Quinton, J. N., Govers, G., Van Oost, K. V., and Bardgett, R. D.: The impact of agricultural soil erosion on biogeochemical sampling, Nature Geosci., 3, 311-314, 2010.
Reiss, J., Bridle, J. R., Montoya, J. M., and Woodward, G.: Emerging horizons in biodiversity and ecosystem functioning research, Trends Ecol. Evol., 24, 505-514, 2009.

Rillig, M. C.: Arbuscular mycorrhizae and terrestrial ecosystem processes, Ecol. Lett., 7, 740-754, 2004.

Rousk, J. and Baath, E.: Fungal biomass production and turnover in soil estimated using the acetate-in-ergosterol technique, Soil Biol. Biochem., 39, 2173-2177, 2007.

Six, J., Frey, S. D., Thiet, R. K., and Batten, K. M.: Bacterial and fungal contributions to carbon sequestration in agroecosystems, Soil Sci. Soc. Am. J., 70, 555-569, 2006.

Smith, R. S., Shiel, R. S., Bardgett, R. D., Millward, D., Corkhill, P., Rolph, G., Hobbs, P. J., and Peacock, S.: Soil microbial community, fertility, vegetation and diversity as targets in the restoration management of a meadow grassland, J. Appl. Ecol., 40, 51-64, 2003.

Smith, P., Chapman, S. J., Scott, W. A., Black, H. I. J., Wattenbach, M., Milne, R., Campbell, C. D., Lilly, A. , Ostle, N., Levy, P. E., Lumsdon, D. G., Millard, P., Towers, W., Zaehle, S., and Smith, J. U.: Climate change cannot be entirely responsible for soil carbon loss observed in England and Wales, 1978-2003, Glob. Change Biol., 13, 2605-2609, 2007.

Smith, R. S., Shiel, R. S., Bardgett, R. D., Millward, D., Corkhill, P., Evans, P., Quirk, H., Hobbs, P. J., and Kometa, S. T.: Longterm change in vegetation and soil microbial communities during the phased restoration of traditional meadow grassland, J. Appl. Ecol., 45, 670-679, 2008.

Stace, C. A.: New Flora of the British Isles Cambridge Univ, Press, Cambridge, 1991.

Strickland, M. S. and Rousk, J.: Considering fungal:bacterial dominance in soils - Methods, controls, and ecosystem implications, Soil Biol. Biochem., 42, 1385-1395, 2010.

Treonis, A. M., Ostle, N. J., Stott, A. W., Primrose, R., Grayston, S. J., and Ineson, P.: Identification of groups of metabolicallyactive rhizosphere microorganisms by stable isotope probing of PLFAs, Soil Biol. Biochem., 36, 533-537, 2004.

van der Heijden, M. G. A, Bardgett, R. D., and van Straalen, N. M.: The unseen majority: soil microbes as drivers of plant diversity and productivity in terrestrial ecosystems, Ecol. Lett., 11, 296310, 2008.

Ward, S. E., Bardgett, R. D., McNamara, N. P., and Ostle, N. J.: Plant functional group identity influences short-term peatland ecosystem carbon flux: evidence from a plant removal experiment, Funct. Ecol., 23, 454-462, 2009.

Woodin, S. J., van der Wal, R., Sommerkorn, M., and Gornall, J. L.: Differential allocation of carbon in mosses and grasses governs ecosystem sequestration: a ${ }^{13} \mathrm{C}$ tracer study in the high Arctic, New Phytol., 184, 944-949, 2009.

Wright, J. P., Naeem, S., Hector, A., Lehman, C., Reich, P. B., Schmid, B., and Tilman, D.: Conventional functional classification schemes underestimate the relationship with ecosystem functioning, Ecol. Lett., 9, 111-120, 2006.

Zelles, L.: Phospholipid fatty acid profiles in selected members of soil microbial communities, Chemosphere, 35, 275-294, 1997. 